\title{
USING THE CRITERION OF THE MINIMUM MATERIAL CAPACITY OF RODS UNDER STABILITY RESTRICTIONS FOR THE CASE OF MULTIPLE CRITICAL LOAD
}

\author{
Leonid S. Lyakhovich ${ }^{1}$, Pavel A. Akimov ${ }^{1,2,3}$, Anatoly P. Malinowski ${ }^{1}$ \\ ${ }^{1}$ Tomsk State University of Architecture and Civil Engineering, Tomsk, RUSSIA \\ ${ }^{2}$ National Research Moscow State University of Civil Engineering, Moscow, RUSSIA \\ ${ }^{3}$ Peoples' Friendship University of Russia, Moscow, RUSSIA
}

\begin{abstract}
As it is known, special criteria are formulated to evaluate the obtained solution of some optimization problems. In particular, we formulate a criterion that allows us to estimate the proximity of the decision on the rod of the lowest weight and the restrictions on the resistance to the minimum material-intensive for rectilinear rods for certain types of cross sections. The criterion is based on the analysis of stresses from bending moments arising from the loss of stability. If the least critical force is not a multiple, then the form of loss of stability and the corresponding diagram of moments are the only ones. At multiplicity of the least critical load there are multiple forms of loss of stability, and any of their linear combination is also its own form. To estimate the obtained solution, it is necessary to form a combination of multiple forms of buckling and the corresponding diagram of bending moments, which will serve as the basis for the use of the criterion. This paper proposes an approach that allows to determine such a combination of multiple forms, which will be the basis for the application of the criterion of proximity of the obtained solution to the minimum material-intensive.
\end{abstract}

Keywords: optimization, system minimal consumption of materials, stability, critical force, buckling, bending moments, multiplicity, tension, evaluation criteria for solutions of optimal problems

\section{ИСПОЛЬЗОВАНИЕ КРИТЕРИЯ МИНИМАЛЬНОЙ МАТЕРИАЛОЕМКОСТИ СТЕРЖНЕЙ ПРИ ОГРАНИЧЕНИЯХ ПО УСТОЙЧИВОСТИ ДЛЯ СЛУЧАЯ КРАТНОЙ КРИТИЧЕСКОЙ НАГРУЗКИ}

\author{
Л.С. Ляхович ${ }^{1}$, П.А. Акимов ${ }^{1,2,3}$, А.П. Малиновский ${ }^{1}$ \\ 1 Томский государственный архитектурно-строительный университет, г. Томск, РОССИЯ \\ ${ }^{2}$ Национальный исследовательский Московский государственный строительный университет, \\ г. Москва, РОССИЯ \\ ${ }^{3}$ Российский университет дружбы народов, г. Москва, РОССИЯ
}

\begin{abstract}
Аннотация: Как известно, для оценки полученного решения некоторых задач оптимизации сформулированы специальные критерии. В частности, сформулирован критерий, позволяющий оценить для прямолинейных стержней при определенных типах поперечных сечений близость решения о стержне наименьшего веса и ограничениях по устойчивости к минимально материалоемкому. Критерий основан на анализе напряжений от изгибающих моментов, возникающих при потере устойчивости. Если наименьшая критическая сила не кратная, то форма потери устойчивости и соответствующая ей эпюра моментов единственные. При кратности наименьшей критической нагрузки возникают кратные формы потери устойчивости, и любая их линейная комбинация также является собственной формой. Для оценки полученного решения необходимо сформировать комбинацию кратных форм потери устойчивости и соответствующую ей эпюру изгибающих моментов, которая и будет служить основой для использования критерия. В данной статье предлагается подход, позволяющий определять такую комбинацию кратных форм, которая станет основой для применения критерия близости полученного решения к минимально материалоемкому.
\end{abstract}


Using the Criterion of the Minimum Material Capacity of Rods Under Stability Restrictions for the Case of Multiple Critical Load

Ключевые слова: оптимизация, системы минимальной материалоемкости, устойчивость, критическая сила, формы потери устойчивости, изгибающие моменты, кратность, напряжения, критерии оценки решений оптимальных задач

The theoretical foundations of the creation of rods of the lowest weight, prone to buckling, originate from the research works of Lagrange [1], T. Clausen [2], EL. Nikolai [2] and later N.G. Chentsova [4]. J.L. Nudelman [5], A.F. Smirnov [6], A.I. Vinogradov [7], N. Olkhoff [8] and other authors.

In the contemporary literature, the considering problem is normally formulated in terms of nonlinear mathematical programming.

Let us consider a centrally compressed straight line rod (for example, shown in Figure 1, although the boundary conditions in the planes of inertia may be different).

If $F(x)$ is the cross-sectional area of the rod, $P$ is the acting force, $P 1_{k p}[1]$ and $P 2_{k p}[1]$ are the minimum critical forces in the main inertia planes of the section, then we need to find an expression $F(x)$ at which the rod would remain stable and the volume of the material of the rod $V$ would be minimal. Thus, the objective function can be written as

$$
V=\int_{0}^{l} F(x) d x,
$$

Besides, we have the following restrictions

$$
P \leq P 1_{k p}[1]=P 2_{k p}[1]
$$

There are a considerable number of methods for solving this problem. Most of them use finitedimensional approaches. The process of optimization within the implementation of such methods most often stops at a stage when the objective function in the adjacent search steps decreases less than a predetermined value. Such a criterion for stopping the process of searching for a minimum in most cases gives an acceptable result. However, it does not allow researcher to confidently estimate the proximity of the so- lution obtained to the solution of minimum material consumption (minimum material-intensive solution).

As a result of several research works $[1,2,3]$ for rectilinear centrally compressed rods with certain types of cross sections (for example, those in which the moment of inertia is proportional to the square of the section area), a criterion was formulated to estimate the proximity of the solution to the solution of minimum material consumption.

In [3], it was shown that in the considering case, the rod of the smallest volume will be a bar of equal resistance with respect to the moment diagram arising in the event of loss of stability. Thus, with a loss of stability with a rod of the smallest volume, the normal stresses in the extreme fibers of the rod, found from the resulting moment diagrams, should be the same in all sections. That is, for the case when the loss of stability occurs in the two main planes of inertia, the criterion is written as

$$
\sigma 1(x)=\text { const } ; \quad \sigma 2(x)=\text { const }
$$

Under conditions (3), $\sigma 1(x)$ and $\sigma 2(x)$ are the absolute values of the normal stresses in the extreme fibers of the rod determined from the diagrams of the moments that occurred in the corresponding principal planes of inertia during loss of stability.

Since the buckling modes and the corresponding moment and stress diagrams are determined to within a constant factor, $\sigma 1(x)$ and $\sigma 2(x)$ are normalized. If the corresponding normalization is made so that the largest values of $\sigma 1(x)$ and $\sigma 2(x)$ would be equal to one, then the proximity of the obtained solution to the solution of minimum material consumption is estimated by the proximity of $\sigma 1(x)$ and $\sigma 2(x)$ to unity. 


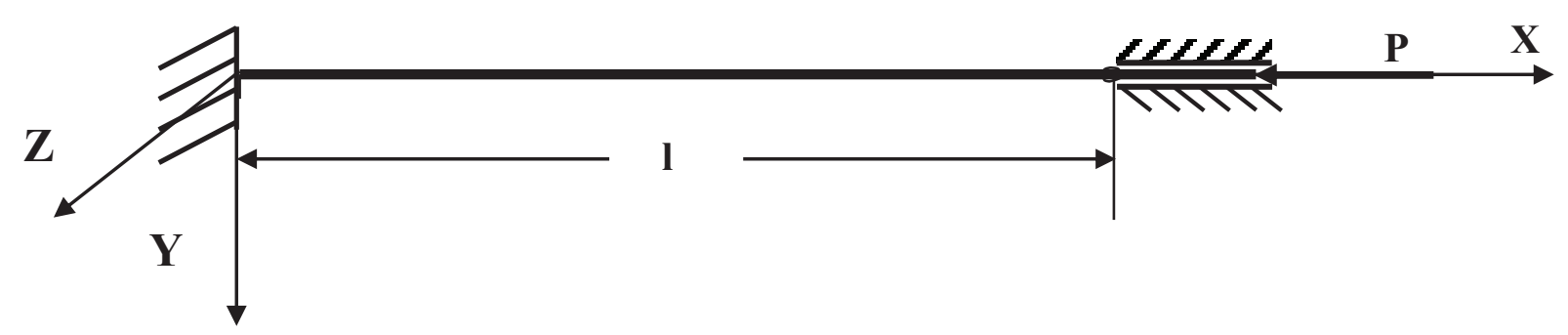

Figure 1. Considering centrally compressed straight line rod.

If the first critical force is not a multiple, then the moment diagram that occurs when stability is lost is unique. In this case, criterion (3) can be used on the basis of this diagram, including in combination with some other restrictions (see, for example, [9]).

If the first critical force is multiple, then multiple buckling modes and the corresponding moment diagrams appear. It is also known that any linear combination of multiple buckling modes will also be proper.

The multiplicity of critical forces that occurs when minimizing the volume of the rod for rigidly restrained rods was identified in [8]. However, the multiplicity of critical forces also occurs in other cases, for example, when optimizing the volume under constraints on the stability of some continuous beam schemes.

In these cases, it is necessary to establish a linear combination of bending moments diagrams corresponding to multiple buckling modes. This combination will serve as the basis for the use of the criterion (3).

Let us consider an approach to determination of such combination. We represent the approach for one main plane of inertia and threefold critical force. For the second plane and the other multiplicity of critical forces, all actions will be similar.

Let it be required to estimate the closeness of the search stage for the solution of the considering optimization problem to the minimum material-intensive one.

At the estimated stage of the search, in the considered main plane of inertia, the first critical forces in $P 1_{c r}[1], P 1_{c r}[2]$ and $P 1_{c r}[3]$ are found, the corresponding forms of buckling and the estimated optimal cross-section sizes and their moments of resistance $w(x)$.

The following steps are performed in the following order:

1. Using the three first forms of buckling found at the estimated stage of the research, the corresponding diagrams of the absolute values of the bending moments $M_{1}(x), M_{2}(x)$ and $M_{3}(x)$ are constructed. Plots are normalized, for example, so that

$$
\begin{gathered}
\int_{0}^{l}\left[M_{1}(x)\right]^{2} d x=1 ; \quad \int_{0}^{l}\left[M_{2}(x)\right]^{2} d x=1 ; \\
\int_{0}^{l}[M 3(x)]^{2} d x=1 .
\end{gathered}
$$

2. On the basis of the assumption about the optimality of the found dimensions of the crosssections, a conditionally optimal diagram of the absolute values of the bending moments $M_{0}(x)$ is constructed, according to which relation (3), that is, the condition,

$$
\sigma 1(x)=\frac{M_{0}(x)}{w(x)}=1
$$

must be fulfilled. Thus, we have $M_{0}(x)=w(x)$. The plot is also normalized.

3 . If the considering solution is optimal, then the combination of arising diagrams

$$
M_{00}(x)=a^{*} M_{1}(x)+b^{*} M_{2}(x)+c^{*} M_{3}(x)
$$


Using the Criterion of the Minimum Material Capacity of Rods Under Stability Restrictions for the Case of Multiple Critical Load

should coincide with $M_{0}(x)$. The equations for finding the coefficients $a, b$ and $c$ will be obtained from the minimum condition of the quadratic deviation of the diagram $M_{00}(x)$ from $M_{0}(x)$. That is, from the minimum condition of the integral

$$
\begin{aligned}
& \Delta M(a, b)= \\
& =\int_{0}^{l}\left[M_{0}(x)-a M_{1}(x)-b M_{2}(x)-c M_{2}(x)\right]^{2} d x,
\end{aligned}
$$

we get three equations

$$
\begin{gathered}
\frac{\partial \Delta M(a, b, c)}{\partial a}=0 ; \quad \frac{\partial \Delta M(a, b, c)}{\partial b}=0 \\
\frac{\partial \Delta M(a, b, c)}{\partial c}=0 .
\end{gathered}
$$

After solution of the system, we can find the coefficients $a, b$ and $c$.

4. From the

$$
M_{00}(x)=a M_{1}(x)+b M_{2}(x)+c M_{3}(x)
$$

plot, we can determine

$$
\sigma l(x)=\frac{M_{0}(x)}{w(x)}
$$

and normalize it, and by the proximity of the stress $\sigma 1(x)$ in sections and its average value along the length of the rod

$$
\Delta \sigma 1=\left[\int_{0}^{\partial} \sigma 1(x) d x\right] / l
$$

to one, we estimate the optimality of the solution.

5. Besides, the optimality of the considering solution can also be evaluated by the proximity of the diagrams of $M_{0}(x)$ and $M_{00}(x)$. The proximity is estimated by the values of the differences

$$
\Delta M_{0}(x)=M_{0}(x)-M_{00}(x)
$$

in the sections and the average value of their absolute values along the length of the rod

$$
\Delta M_{00}=\left\{\int_{0}^{l} \operatorname{sgn}\left[\Delta M_{0}(x)\right] \Delta M_{0}(x) d x\right\} / l .
$$

6. If the multiplicity of critical forces for the considering system is not known in advance, then its presence or absence is revealed in the process of optimization. If the multiplicity is detected, then the differences

$$
\begin{aligned}
& \Delta P 1=\left\{P 1_{k p}[2]-P 1_{k p}[1]\right\} / P 1_{k p}[1] \cdot 100 \% ; \\
& \Delta P 2=\left\{P 1_{k p}[3]-P 1_{k p}[1]\right\} / P 1_{k p}[1] \cdot 100 \%
\end{aligned}
$$

in the limit tend to zero. Let us give an illustration of the described approach with samples.

7. For a rod whose scheme is shown in Figure 1 , the doubling of the critical force was considered in detail in [8]. Although the possibility of using of the criterion (3) was not considered in [8], taking into account the detailed analysis in [8] of the doubly critical load of a rigidly clamped rod, it seems appropriate to illustrate the proposed approach using other examples. Two numerical samples are considered. The first one deals with two-time critical force, and the second one deals with three-time critical force.

The first numerical sample. Let us consider a rectilinear square rod, compressed by a centrally applied longitudinal force with supporting conditions in both main planes of inertia of sections, shown in Figure 2.

A preliminary analysis showed that the critical force will be twofold.

Let $l=9$ meters be width of span, $P=3000000 \quad N$ be magnitude of force;

$E=206000 \mathrm{MPa}$ be the modulus of elasticity of the material. The analysis was performed on the basis of a discrete model ([10]) of 41 fragments. 


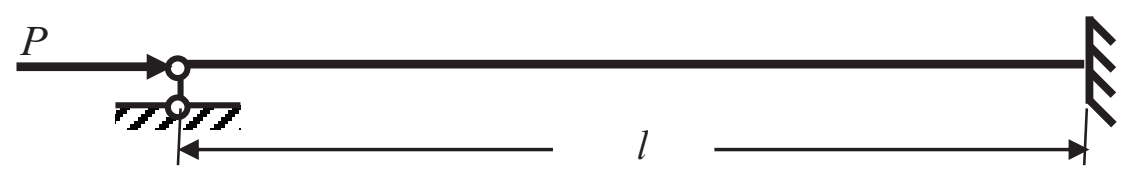

Figure 1. The first numerical sample.

For a discrete model, the objective function (1) is written as

$$
V=\sum_{1}^{n} F[i](l / n)=\sum_{1}^{n}(b[i])^{2}(l / n)
$$

where $b[i]$ is the size of the square section of the rod; $n$ is dimension of a discrete model.

Diagrams of $M_{1}(x), M_{2}(x), M_{0}(x), M_{00}(x)$, $\Delta M_{0}(x)$ are represented by $M_{1}[i], M_{2}[i]$, $M_{3}[i], M_{00}[i], \Delta M_{0}[i]$.

Since the boundary conditions in both main planes of inertia are the same, and the critical forces are assumed to be twofold, the stability constraints are written as

$$
P \leq P 1_{k p}[1]=P 1_{k p}[2] .
$$

Criterion (3) for the discrete model in this case takes the form

$$
\sigma[i]=\text { const }
$$

Optimization was performed by one of the variants of the method of random search. The estimation of the proximity of the solution to the minimum material-based on criterion (6) was carried out at several stages of the computing (Tables 1 and 2).

Four stages were considered. The results of each stage are presented in the corresponding columns of Tables 1 and 2. Stage 0 corresponds to the results corresponding to the first access to the boundary of the allowable area for a rod of constant square cross-sectional length. The remaining columns show the results, respectively, at 300, 1300 and more than 40,000 tests of the random search method. Table 1 shows the cross-section dimensions $b[i]$ for each stage. The bottom five lines show the values of the objective function $-V$, meters ${ }^{3}$; the magnitudes of its decrease compared with stage $0-\Delta V, \%$; the difference between the first two critical forces $-\Delta P, \%$; the values of the coefficients $a$ and $b$.

Table 2 shows the values of the differences

$$
\Delta M_{0}[i]=M_{0}[i]-M_{00}[i]
$$

and stresses $\sigma[i]$, and in the last line the average values for each stage are the values of these quantities $\Delta M_{00}$ and $\Delta \sigma 1$.

Analysis of the data in tables 1 and 2 shows that despite the small difference in the values of the objective function in the last two stages, the difference in cross sections between the values of differences $\Delta M_{0}[i]$ and stresses $\sigma[i]$ at these stages of the search is more significant. At the last stage, in almost all cross sections, the differences $\Delta M_{0}[i]$ are close to zero, and the stresses $\sigma[i]$ to unity.

The result obtained confirms that, even with a double critical force, criterion (3) can estimate the proximity of the obtained solution to the minimum material-intensive one.

Let us consider one more example, in which, according to preliminary calculations during optimization, the critical force turns out to be threefold.

Let us consider a rectilinear square rod, compressed by a centrally applied longitudinal force with supporting conditions in both main planes of inertia of sections, shown in Figure 3. 
Using the Criterion of the Minimum Material Capacity of Rods Under Stability Restrictions for the Case of Multiple Critical Load

Table 1. Results of analysis.

\begin{tabular}{|c|c|c|c|c|}
\hline & \multicolumn{4}{|c|}{$b[i]$ by stages of search for optimum } \\
\hline$t$ & 0 & 300 & 1300 & $>40000$ \\
\hline 1 & 2 & 3 & 4 & 5 \\
\hline 1 & 0.0915 & 0.0626 & 0.0420 & 0.0426 \\
\hline 2 & 0.0915 & 0.0655 & 0.0600 & 0.0596 \\
\hline 3 & 0.0915 & 0.0789 & 0.0696 & 0.0692 \\
\hline 4 & 0.0915 & 0.0784 & 0.0761 & 0.0761 \\
\hline 5 & 0.0915 & 0.0835 & 0.0806 & 0.0813 \\
\hline 6 & 0.0915 & 0.0821 & 0.0855 & 0.0854 \\
\hline 7 & 0.0915 & 0.0927 & 0.0878 & 0.0888 \\
\hline 8 & 0.0915 & 0.0883 & 0.0921 & 0.0916 \\
\hline 9 & 0.0915 & 0.0949 & 0.0943 & 0.0938 \\
\hline 10 & 0.0915 & 0.0984 & 0.0966 & 0.0957 \\
\hline 11 & 0.0915 & 0.0949 & 0.0960 & 0.0971 \\
\hline 12 & 0.0915 & 0.0924 & 0.0985 & 0.0982 \\
\hline 13 & 0.0915 & 0.0944 & 0.0982 & 0.0990 \\
\hline 14 & 0.0915 & 0.1110 & 0.0987 & 0.0995 \\
\hline 15 & 0.0915 & 0.0975 & 0.1000 & 0.0997 \\
\hline 16 & 0.0915 & 0.1010 & 0.0990 & 0.0997 \\
\hline 17 & 0.0915 & 0.0995 & 0.1000 & 0.0993 \\
\hline 18 & 0.0915 & 0.0929 & 0.0987 & 0.0986 \\
\hline 19 & 0.0915 & 0.1189 & 0.0988 & 0.0977 \\
\hline 20 & 0.0915 & 0.1021 & 0.0967 & 0.0964 \\
\hline 21 & 0.0915 & 0.1053 & 0.0944 & 0.0948 \\
\hline 22 & 0.0915 & 0.0833 & 0.0925 & 0.0927 \\
\hline 23 & 0.0915 & 0.0998 & 0.0905 & 0.0902 \\
\hline 24 & 0.0915 & 0.0799 & 0.0877 & 0.0872 \\
\hline 25 & 0.0915 & 0.0857 & 0.0829 & 0.0834 \\
\hline 26 & 0.0915 & 0.0787 & 0.0784 & 0.0787 \\
\hline 27 & 0.0915 & 0.0806 & 0.0724 & 0.0728 \\
\hline 28 & 0.0915 & 0.0654 & 0.0639 & 0.0647 \\
\hline 29 & 0.0915 & 0.0743 & 0.0522 & 0.0523 \\
\hline 30 & 0.0915 & 0.0701 & 0.0255 & 0.0049 \\
\hline 31 & 0.0915 & 0.0730 & 0.0524 & 0.0518 \\
\hline 32 & 0.0915 & 0.0603 & 0.0644 & 0.0640 \\
\hline 33 & 0.0915 & 0.0636 & 0.0731 & 0.0719 \\
\hline 34 & 0.0915 & 0.0793 & 0.0776 & 0.0777 \\
\hline 35 & 0.0915 & 0.0736 & 0.0828 & 0.0823 \\
\hline 36 & 0.0915 & 0.0834 & 0.0852 & 0.0859 \\
\hline 37 & 0.0915 & 0.0966 & 0.0899 & 0.0888 \\
\hline 38 & 0.0915 & 0.1000 & 0.0917 & 0.0912 \\
\hline 39 & 0.0915 & 0.0911 & 0.0924 & 0.0931 \\
\hline 40 & 0.0915 & 0.0889 & 0.0944 & 0.0946 \\
\hline
\end{tabular}


Leonid S. Lyakhovich, Pavel A. Akimov, Anatoly P. Malinowski

\begin{tabular}{|c|c|c|c|c|}
\hline 1 & 2 & 3 & 4 & 5 \\
\hline 41 & 0.0915 & 0.0852 & 0.0956 & 0.0957 \\
\hline$V$, meters $^{3}$ & 0.07539 & 0.06904 & 0.06492 & 0.06476 \\
\hline$\Delta V$ & $0.00 \%$ & $8.43 \%$ & $13.89 \%$ & $14.10 \%$ \\
\hline$\Delta P$ & $195.00 \%$ & $130.49 \%$ & $17.74 \%$ & $0.03 \%$ \\
\hline$a$ & 0.48987 & 0.83099 & 1.01063 & 1,02480 \\
\hline$b$ & 0.49986 & 0.13279 & -0.01283 & $-0,02805$ \\
\hline
\end{tabular}

Table 2. Results of analysis.

\begin{tabular}{|c|c|c|c|c|c|c|c|c|}
\hline \multirow[b]{2}{*}{$t$} & \multicolumn{4}{|c|}{$\Delta M_{0}[i]$ by stages of search for optimum } & \multicolumn{4}{|c|}{$\sigma$ by stages of search for optimum } \\
\hline & 0 & 300 & 1300 & $>40000$ & 0 & 300 & 1300 & $>40000$ \\
\hline 1 & 2 & 3 & 4 & 5 & 6 & 7 & 8 & 9 \\
\hline 1 & 0.1396 & 0.0388 & 0.0008 & 0.0000 & 0.076842 & 0.135799 & 0.978754 & 0.9988 \\
\hline 2 & 0.1070 & 0.0284 & 0.0019 & 0.0001 & 0.228466 & 0.301949 & 0.893968 & 0.9973 \\
\hline 3 & 0.0757 & 0.0202 & 0.0024 & 0.0000 & 0.373973 & 0.476454 & 0.902065 & 0.9984 \\
\hline 4 & 0.0465 & 0.0256 & 0.0019 & 0.0000 & 0.509501 & 0.441546 & 0.913346 & 0.9986 \\
\hline 5 & 0.0202 & 0.0003 & 0.0010 & 0.0000 & 0.631502 & 0.597886 & 0.923345 & 0.9985 \\
\hline 6 & 0.0025 & 0.0103 & 0.0032 & 0.0000 & 0.736850 & 0.541898 & 0.952999 & 0.9988 \\
\hline 7 & 0.0210 & 0.0334 & 0.0064 & 0.0000 & 0.822944 & 0.718689 & 0.971152 & 0.9988 \\
\hline 8 & 0.0350 & 0.0815 & 0.0001 & 0.0000 & 0.887779 & 0.941500 & 0.930939 & 0.9987 \\
\hline 9 & 0.0441 & 0.0678 & 0.0041 & 0.0000 & 0.930011 & 0.827215 & 0.910997 & 0.9990 \\
\hline 10 & 0.0481 & 0.0215 & 0.0091 & 0.0000 & 0.948989 & 0.662066 & 0.889453 & 0.9990 \\
\hline 11 & 0.0472 & 0.0239 & 0.0144 & 0.0000 & 0.944770 & 0.514969 & 1.000000 & 0.9987 \\
\hline 12 & 0.0415 & 0.0293 & 0.0056 & 0.0000 & 0.918104 & 0.487964 & 0.907040 & 0.9989 \\
\hline 13 & 0.0312 & 0.0782 & 0.0094 & 0.0001 & 0.870409 & 0.867698 & 0.973216 & 0.9991 \\
\hline 14 & 0.0169 & 0.1005 & 0.0105 & 0.0000 & 0.803706 & 0.381801 & 0.977651 & 0.9987 \\
\hline 15 & 0.0010 & 0.0407 & 0.0069 & 0.0000 & 0.720548 & 0.468211 & 0.902845 & 0.9987 \\
\hline 16 & 0.0218 & 0.0869 & 0.0025 & 0.0000 & 0.623928 & 0.350193 & 0.921093 & 0.9986 \\
\hline 17 & 0.0448 & 0.0572 & 0.0006 & 0.0001 & 0.517169 & 0.765660 & 0.929211 & 0.9991 \\
\hline 18 & 0.0347 & 0.0903 & 0.0021 & 0.0001 & 0.564413 & 0.924885 & 0.940865 & 0.9990 \\
\hline 19 & 0.0191 & 0.1114 & 0.0039 & 0.0000 & 0.636604 & 0.402981 & 0.914728 & 0.9988 \\
\hline 20 & 0.0061 & 0.1037 & 0.0092 & 0.0001 & 0.697070 & 0.312453 & 0.888763 & 0.9984 \\
\hline 21 & 0.0038 & 0.0158 & 0.0016 & 0.0000 & 0.743026 & 0.556928 & 0.923710 & 0.9985 \\
\hline 22 & 0.0101 & 0.0800 & 0.0006 & 0.0001 & 0.772075 & 1.000000 & 0.928379 & 0.9992 \\
\hline 23 & 0.0123 & 0.0377 & 0.0066 & 0.0000 & 0.782309 & 0.485707 & 0.894467 & 0.9988 \\
\hline 24 & 0.0101 & 0.0041 & 0.0022 & 0.0001 & 0.772383 & 0.572689 & 0.918233 & 0.9982 \\
\hline 25 & 0.0035 & 0.0387 & 0.0057 & 0.0000 & 0.741573 & 0.416936 & 0.973638 & 0.9984 \\
\hline 26 & 0.0077 & 0.0122 & 0.0055 & 0.0000 & 0.689821 & 0.669361 & 0.979892 & 0.9989 \\
\hline 27 & 0.0232 & 0.0177 & 0.0015 & 0.0000 & 0.617743 & 0.497582 & 0.915495 & 0.9984 \\
\hline 28 & 0.0428 & 0.0142 & 0.0031 & 0.0000 & 0.526627 & 0.744256 & 0.982150 & 0.9985 \\
\hline 29 & 0.0661 & 0.0478 & 0.0002 & 0.0000 & 0.418400 & 0.256604 & 0.938477 & 0.9988 \\
\hline 30 & 0.0723 & 0.0574 & 0.0035 & 0.0000 & 0.389795 & 0.110365 & 0.055568 & -0.0546 \\
\hline 31 & 0.0772 & 0.0454 & 0.0007 & 0.0000 & 0.366997 & 0.255342 & 0.910506 & 1.0000 \\
\hline 32 & 0.0843 & 0.0037 & 0.0032 & 0.0000 & 0.333614 & 0.644771 & 0.880962 & 0.9992 \\
\hline 33 & 0.0933 & 0.0282 & 0.0051 & 0.0000 & 0.292105 & 0.915174 & 0.876885 & 0.9992 \\
\hline
\end{tabular}


Using the Criterion of the Minimum Material Capacity of Rods Under Stability Restrictions for the Case of Multiple Critical Load

\begin{tabular}{|c|c|c|c|c|c|c|c|c|}
\hline 1 & 2 & 3 & 4 & 5 & 6 & 7 & 8 & 9 \\
\hline 34 & 0.0969 & 0.0431 & 0.0044 & 0.0000 & 0.275390 & 0.343807 & 0.971364 & 0.9987 \\
\hline 35 & 0.0660 & 0.0390 & 0.0017 & 0.0000 & 0.418961 & 0.881604 & 0.919258 & 0.9988 \\
\hline 36 & 0.1541 & 0.0365 & 0.0028 & 0.0001 & 0.554891 & 0.412768 & 0.950408 & 0.9995 \\
\hline 37 & 0.1713 & 0.0655 & 0.0045 & 0.0000 & 0.679382 & 0.384630 & 0.905781 & 0.9986 \\
\hline 38 & 0.1864 & 0.0676 & 0.0004 & 0.0001 & 0.788944 & 0.399366 & 0.929533 & 0.9985 \\
\hline 39 & 0.1994 & 0.0502 & 0.0013 & 0.0001 & 0.880504 & 0.402443 & 0.938544 & 0.9992 \\
\hline 40 & 0.2099 & 0.0156 & 0.0064 & 0.0000 & 0.951507 & 0.661024 & 0.899818 & 0.9987 \\
\hline 41 & 0.2179 & 0.0131 & 0.0077 & 0.0001 & 1.000000 & 0.657937 & 0.968563 & 0.9983 \\
\hline$\Sigma / n$ & 0.0408 & 0.0435 & 0.0040 & 0.0000 & 0.6449 & 0.5461 & 0.9094 & 0.9731 \\
\hline
\end{tabular}

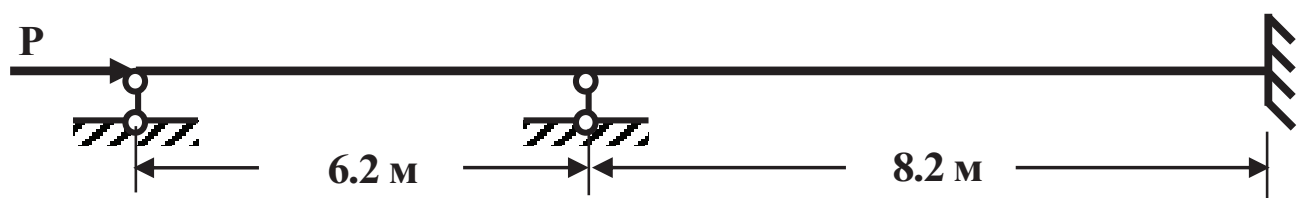

Figure 2. The second numerical sample.

The second numerical sample. Let us consider a rectilinear square rod, compressed by a centrally applied longitudinal force with supporting conditions in both main planes of inertia of sections, shown in Figure 3. The analysis was performed on the basis of a discrete model ([10]) of 41 fragments.

Since the boundary conditions in the two main planes of inertia are the same, and the critical forces are assumed to be threefold, the stability constraints are written as

$$
P \leq P 1_{c r}[1]=P 1_{c r}[2]=P 1_{c r}[3]
$$

In the same way as in the first sample, optimization was performed by one of the variants of the random search method. The estimation of the proximity of the solution to the minimum material-based on criterion (6) was carried out at several stages of the calculation (Tables 3 and 4). Similarly to the first sample, four stages of finding the optimal solution were considered.

The results are presented in the corresponding columns of Tables 3 and 4 . The designations in these tables are the same as in the first sample. In addition, Table 3 also lists the values of the coefficient $c$ and the difference $\triangle P 2$.
Analysis of the data in Tables 3 and 4 shows that in the last two stages of the search, the objective functions differ little.

However, at the same time, differences $\Delta M_{0}[i]$ and reduced stresses $\sigma[i]$ show that, despite the small difference in the values of the objective function in the last two stages, the difference between the values of differences $\Delta M_{0}[i]$ and stresses $\sigma[i]$ at these stages of the search is more significant. At the last stage, in almost all cross sections, the differences $\Delta M_{0}[i]$ are close to zero, and the stresses $\sigma[i]$ to unity. In sections 16 and 31, the stresses are far from unity. This is due to the significantly smaller compared with the other sizes of sections, which in such cases reduces the accuracy of the selected model.

From Table 3 it can be seen how the critical forces approach each other in stages. So, if at stage number 0 the difference $\Delta P 1$ is $102.54 \%$, and $\triangle P 2-236.62 \%$, then at the last stage these differences are $0.01 \%$ and $0.03 \%$.

Table 4 shows how the mean values of differences $\Delta M_{00}$ and stresses change $\Delta \sigma 1$. 
Table 3. Results of analysis.

\begin{tabular}{|c|c|c|c|c|}
\hline & \multicolumn{4}{|c|}{$b[i]$ by stages of search for optimum } \\
\hline$t$ & 0 & 300 & 1300 & $>40000$ \\
\hline 1 & 2 & 3 & 4 & 5 \\
\hline 0.0893 & 0.0500 & 0.0503 & 0.0513 & 0.0893 \\
\hline 0.0893 & 0.0724 & 0.0711 & 0.0705 & 0.0893 \\
\hline 0.0893 & 0.0745 & 0.0818 & 0.0808 & 0.0893 \\
\hline 0.0893 & 0.0865 & 0.0882 & 0.0875 & 0.0893 \\
\hline 0.0893 & 0.0972 & 0.0925 & 0.0920 & 0.0893 \\
\hline 0.0893 & 0.0936 & 0.0951 & 0.0950 & 0.0893 \\
\hline 0.0893 & 0.1072 & 0.0967 & 0.0968 & 0.0893 \\
\hline 0.0893 & 0.0991 & 0.0987 & 0.0976 & 0.0893 \\
\hline 0.0893 & 0.0968 & 0.0950 & 0.0973 & 0.0893 \\
\hline 0.0893 & 0.0980 & 0.0951 & 0.0960 & 0.0893 \\
\hline 0.0893 & 0.0990 & 0.0930 & 0.0936 & 0.0893 \\
\hline 0.0893 & 0.0901 & 0.0913 & 0.0898 & 0.0893 \\
\hline 0.0893 & 0.0779 & 0.0848 & 0.0842 & 0.0893 \\
\hline 0.0893 & 0.0807 & 0.0765 & 0.0759 & 0.0893 \\
\hline 0.0893 & 0.0637 & 0.0631 & 0.0623 & 0.0893 \\
\hline 0.0893 & 0.0477 & 0.0260 & 0.0057 & 0.0893 \\
\hline 0.0893 & 0.0557 & 0.0609 & 0.0618 & 0.0893 \\
\hline 0.0893 & 0.0748 & 0.0758 & 0.0753 & 0.0893 \\
\hline 0.0893 & 0.0872 & 0.0832 & 0.0834 & 0.0893 \\
\hline 0.0893 & 0.0881 & 0.0894 & 0.0889 & 0.0893 \\
\hline 0.0893 & 0.0908 & 0.0925 & 0.0925 & 0.0893 \\
\hline 0.0893 & 0.0879 & 0.0943 & 0.0947 & 0.0893 \\
\hline 0.0893 & 0.0967 & 0.0959 & 0.0958 & 0.0893 \\
\hline 0.0893 & 0.0898 & 0.0947 & 0.0958 & 0.0893 \\
\hline 0.0893 & 0.0869 & 0.0941 & 0.0947 & 0.0893 \\
\hline 0.0893 & 0.0963 & 0.0922 & 0.0925 & 0.0893 \\
\hline 0.0893 & 0.0867 & 0.0888 & 0.0888 & 0.0893 \\
\hline 0.0893 & 0.0811 & 0.0831 & 0.0834 & 0.0893 \\
\hline 0.0893 & 0.0798 & 0.0757 & 0.0753 & 0.0893 \\
\hline 0.0893 & 0.0604 & 0.0622 & 0.0618 & 0.0893 \\
\hline 0.0893 & 0.0457 & 0.0242 & 0.0057 & 0.0893 \\
\hline 0.0893 & 0.0676 & 0.0611 & 0.0602 & 0.0893 \\
\hline 0.0893 & 0.0785 & 0.0733 & 0.0731 & 0.0893 \\
\hline 0.0893 & 0.0807 & 0.0811 & 0.0806 & 0.0893 \\
\hline 0.0893 & 0.0884 & 0.0849 & 0.0854 & 0.0893 \\
\hline 0.0893 & 0.0957 & 0.0880 & 0.0883 & 0.0893 \\
\hline$V$, meters $^{3}$ & 0.1149 & 0.1003 & 0.0978 & 0.0973 \\
\hline$\Delta V$ & 0.00 & 12.69 & 14.90 & 15.35 \\
\hline$\Delta P 1$ & 102.54 & 31.20 & 5.72 & 0.01 \\
\hline$\triangle P 2$ & 236.62 & 71.35 & 9.42 & 0.03 \\
\hline
\end{tabular}


Using the Criterion of the Minimum Material Capacity of Rods Under Stability Restrictions for the Case of Multiple Critical Load

\begin{tabular}{|c|c|c|c|c|}
\hline 1 & 2 & 3 & 4 & 5 \\
\hline$a$ & 0.2813 & 0.8000 & 0.8283 & 0.5434 \\
\hline$b$ & 0.3571 & 0.1761 & 0.1846 & 0.4334 \\
\hline$c$ & 0.3932 & 0.0045 & -0.0101 & 0.0516 \\
\hline
\end{tabular}

Table 2. Results of analysis.

\begin{tabular}{|c|c|c|c|c|c|c|c|c|}
\hline & \multicolumn{4}{|c|}{$\begin{array}{l}\Delta M_{0}[i] \text { by stages of search } \\
\text { for optimum }\end{array}$} & \multicolumn{4}{|c|}{$\sigma$ by stages of search for optimum } \\
\hline$t$ & 0 & 300 & 1300 & $>40000$ & 0 & 300 & 1300 & $>40000$ \\
\hline 1 & 2 & 3 & 4 & 5 & 6 & 7 & 8 & 9 \\
\hline 1 & 0.1302 & 0.0087 & 0.0043 & 0.0000 & 0.1554 & 0.4562 & 0.9797 & 0.9995 \\
\hline 2 & 0.0610 & 0.0332 & 0.0035 & 0.0000 & 0.4501 & 0.4111 & 0.8332 & 0.9992 \\
\hline 3 & 0.0029 & 0.0161 & 0.0075 & 0.0000 & 0.6979 & 0.5343 & 0.8202 & 0.9991 \\
\hline 4 & 0.0385 & 0.0139 & 0.0031 & 0.0002 & 0.8741 & 0.6878 & 0.8815 & 0.9974 \\
\hline 5 & 0.0591 & 0.0696 & 0.0043 & 0.0002 & 0.9623 & 0.4408 & 0.8482 & 0.9998 \\
\hline 6 & 0.0578 & 0.0032 & 0.0030 & 0.0000 & 0.9565 & 0.6429 & 0.8547 & 0.9988 \\
\hline 7 & 0.0355 & 0.0852 & 0.0131 & 0.0000 & 0.8616 & 0.4575 & 0.9148 & 0.9988 \\
\hline 8 & 0.0042 & 0.0033 & 0.0048 & 0.0000 & 0.6924 & 0.6418 & 0.8495 & 0.9987 \\
\hline 9 & 0.0319 & 0.0418 & 0.0144 & 0.0001 & 0.5743 & 0.5161 & 0.9224 & 0.9984 \\
\hline 10 & 0.0299 & 0.0824 & 0.0012 & 0.0001 & 0.5827 & 0.4106 & 0.8710 & 0.9992 \\
\hline 11 & 0.0391 & 0.0502 & 0.0028 & 0.0001 & 0.5436 & 0.7646 & 0.8545 & 0.9995 \\
\hline 12 & 0.0111 & 0.0683 & 0.0133 & 0.0001 & 0.6630 & 0.8699 & 0.8078 & 0.9984 \\
\hline 13 & 0.0007 & 0.0358 & 0.0067 & 0.0000 & 0.7133 & 0.8247 & 0.8294 & 0.9985 \\
\hline 14 & 0.0055 & 0.0431 & 0.0063 & 0.0000 & 0.6869 & 0.4253 & 0.8194 & 0.9989 \\
\hline 15 & 0.0292 & 0.0192 & 0.0029 & 0.0000 & 0.5859 & 0.4439 & 0.8273 & 0.9990 \\
\hline 16 & 0.0505 & 0.0094 & 0.0007 & 0.0000 & 0.4952 & 0.8522 & 1.0000 & 0.5329 \\
\hline 17 & 0.0533 & 0.0249 & 0.0017 & 0.0000 & 0.4831 & 1.0000 & 0.8408 & 0.9987 \\
\hline 18 & 0.0199 & 0.0160 & 0.0038 & 0.0000 & 0.6253 & 0.5361 & 0.8372 & 0.9989 \\
\hline 19 & 0.0013 & 0.0875 & 0.0052 & 0.0002 & 0.7048 & 0.2975 & 0.8363 & 1.0000 \\
\hline 20 & 0.0002 & 0.0171 & 0.0114 & 0.0000 & 0.7092 & 0.5696 & 0.8127 & 0.9988 \\
\hline 21 & 0.0053 & 0.0234 & 0.0053 & 0.0001 & 0.6877 & 0.5537 & 0.8886 & 0.9984 \\
\hline 22 & 0.0104 & 0.0662 & 0.0010 & 0.0000 & 0.7544 & 0.8805 & 0.8702 & 0.9989 \\
\hline 23 & 0.0077 & 0.0523 & 0.0051 & 0.0000 & 0.7430 & 0.4862 & 0.8467 & 0.9988 \\
\hline 24 & 0.0115 & 0.0459 & 0.0006 & 0.0000 & 0.6612 & 0.7939 & 0.8686 & 0.9986 \\
\hline 25 & 0.0213 & 0.0236 & 0.0032 & 0.0001 & 0.6193 & 0.5421 & 0.8790 & 0.9983 \\
\hline 26 & 0.0129 & 0.0406 & 0.0087 & 0.0000 & 0.7653 & 0.7485 & 0.9035 & 0.9990 \\
\hline 27 & 0.0305 & 0.0474 & 0.0042 & 0.0001 & 0.8400 & 0.4487 & 0.8862 & 0.9996 \\
\hline 28 & 0.0275 & 0.0163 & 0.0098 & 0.0001 & 0.8275 & 0.7107 & 0.9236 & 0.9993 \\
\hline 29 & 0.0028 & 0.0230 & 0.0039 & 0.0001 & 0.7223 & 0.5182 & 0.8358 & 0.9979 \\
\hline 30 & 0.0422 & 0.0090 & 0.0020 & 0.0000 & 0.5305 & 0.7365 & 0.8940 & 0.9990 \\
\hline 31 & 0.0851 & 0.0091 & 0.0020 & 0.0000 & 0.3474 & 0.3901 & 0.3920 & 0.1702 \\
\hline 32 & 0.0945 & 0.0139 & 0.0011 & 0.0000 & 0.3074 & 0.5187 & 0.8505 & 0.9981 \\
\hline 33 & 0.0855 & 0.0221 & 0.0006 & 0.0000 & 0.3460 & 0.7489 & 0.8712 & 0.9984 \\
\hline 34 & 0.0183 & 0.0742 & 0.0054 & 0.0000 & 0.6321 & 0.9912 & 0.8322 & 0.9989 \\
\hline 35 & 0.0349 & 0.0245 & 0.0016 & 0.0001 & 0.8589 & 0.7232 & 0.8750 & 0.9993 \\
\hline
\end{tabular}




\begin{tabular}{|c|c|c|c|c|c|c|c|c|}
\hline 1 & 2 & 3 & 4 & 5 & 6 & 7 & 8 & 9 \\
\hline 36 & 0.0680 & 0.0961 & 0.0004 & 0.0000 & 1.0000 & 0.3548 & 0.8682 & 0.9987 \\
\hline$\Sigma / n$ & 0.0339 & 0.0366 & 0.0047 & 0.0001 & 0.6572 & 0.6091 & 0.8535 & 0.9629 \\
\hline
\end{tabular}

So, if in the first three stages the average value of the differences $\Delta M_{00}$ is far from zero. Besides, the average stress $\Delta \sigma 1$ is far from one. Thus we have $\Delta M_{00}=0.0001$ and $\Delta \sigma 1=0.9993$ at the last stage.

The result obtained in this sample confirms that with a triple critical force criterion (3) can estimate the closeness of the obtained solution to the minimum material-intensive one.

The approach proposed in this paper is based on using the criterion (3) of estimating the proximity of a solution for optimizing rods with constraints on resistance to the least materialintensive. This approach can be extended to cases of multiplicity of critical forces.

\section{REFERENCES}

1. Lagrange J.-L. Sur la Figure Des Collonnes. // Mescellanea Taurinensia, 17701773, Vol. 5, pp. 123.

2. Clausen T. Uber die Form Architektonischer Säulen. // Bull. cl. physico-raath. Acad. St.-Petersbourg, 1851, Vol. IX, pp. 371-380.

3. Nikolay E.L. Zadacha Lagranzha o Naivygodnejshem Ochertanii Kolonny [Lagrange's Problem About the Most Advantageous Outline of a Column]. // News. Of St. Petersburg Polytechnic Institute, 1907, Vol. VIII.

4. Chentsov N.G. Stojki Naimen'shego Vesa [Stands of a Minimum Weight]. // Trudy TSAGI, 1936, Vol. 265.

5. Nudelman Ya.L. Metody Opredelenija Sobstvennyh Chastot i Kriticheskih Sil Dlja Sterzhnevyh Sistem [Methods for Determining Natural Frequencies and Critical Forces for Rod Systems]. Moscow, Gostekhizdat, 1949, 175 pages.

6. Smirnov A.F. Ustojchivost' i Kolebanija Sooruzhenij [Stability and Oscillations of
Structures]. Moscow, Transzheldorizdat, 1958.

7. Vinogradov A.I. Problema Optimal'nogo Proektirovanija v Stroitel'noj Mehanike [The Problem of Optimal Design in Structural Mechanics]. Kyiv, Vyscha Shkola Publishing House in Kharkiv University, 1973, 167 pages.

8. Olhoff, N, Rasmussen S.Kh. O Prostyh i Dvuhkratnyh Optimal'nyh Kriticheskih Nagruzkah Poteri Ustojchivosti Dlja Zashhemlennyh Sterzhnej [On Simple and TwoFold the Optimal Critical Load of Buckling for the Clamped Rods]. // Mechanics. New in Foreign Science. Optimal Design of Structures, 1981, Vol. 27, pp. 139-154.

9. Lyakhovich L.S. Osobye Svojstva Optimal'nyh Sistem i Osnovnye Napravlenija ih Realizacii v Metodah Rascheta Sooruzhenij [Special Properties of Optimal Systems and the Main Directions of Their Implementation in the Methods of Calculation of Structures]. Tomsk, Tomsk State University of Architecture and Construction, 2009, 372 pages.

10. Malinovsky A.P. Chislennyj Metod Rascheta Sterzhnej na Prochnost', Ustojchivost' i Kolebanija [A Numerical Method of Calculation of the Studs for Strength, Stability and Fluctuations]. // Studies in Structures and Structural Mechanics. Tomsk: Publishing House of TSU, 1978, pp. 85-96.

\section{СПИСОК ПУБЛИКАЦИЙ}

1. Lagrange J.-L. Sur la Figure Des Collonnes. // Mescellanea Taurinensia, 17701773, Vol. 5, pp. 123.

2. Clausen T. Uber die Form Architektonischer Säulen. // Bull. cl. physico-raath. 
Using the Criterion of the Minimum Material Capacity of Rods Under Stability Restrictions for the Case of Multiple Critical Load

Acad. St.-Petersbourg, 1851, Vol. IX, pp. 371-380.

3. Николаи Е.Л. Задача Лагранжа о наивыгоднейшем очертании колонны. // Известия Санкт-Петербургского политехнического института, 1907, т. VIII.

4. Ченцов Н.Г. Стойки наименьшего весаю // Труды ЦАГИ, 1936, Вып. 265.

5. Нудельман Я.Л., Методы определения собственных частот и критических сил для стержневых систем. - М.: Гостехиздат, 1949. - 175 с.

6. Смирнов А.Ф. Устойчивость и колебания сооружений. - М.: Трансжелдориздат, 1958.

7. Виноградов А.И. Проблема оптимального проектирования в строительной механике. - Харьков: Вища школа, Издательство при Харьковском университете, 1973. - $167 \mathrm{c}$

8. Ольхофф Н, Расмуссен С.Х. О простых и двухкратных оптимальных критических нагрузках потери устойчивости для защемленных стержней. // Механика. Новое в зарубежной науке. Оптимальное проектирование конструкций, 1981, №27, c. 139-154.

9. Ляхович Л.С. Особые свойства оптимальных систем и основные направления их реализации в методах расчета сооружений. - Томск: Издательство Томского государственного архитектурностроительного университета, 2009. - 372 c.

10. Малиновский А.П. Численный метод расчета стержней на прочность, устойчивость и колебания. // Исследования по строительным конструкциям и строительной механике. - Томск: Издательство ТГУ, 1978, с. 85-96.

Ляхович Леонид Семенович, академик РААСН, профессор, доктор технических наук, профессор кафедры строительной механики, Томский государственный архитектурно-строительный университет; 634003, Россия, г. Томск, Соляная пл. 2;

E-mail: 1ls@tsuab.ru
Акимов Павел Алексеевич, академик РААСН, профессор, доктор технических наук; временно исполняющий обязанности ректора Национального исследовательского Московского государственного строительного университета; профессор Департамента архитектуры и строительства Российского университета дружбы народов; профессор кафедры строительной механики Томского государственного архитектурностроительного университета; 107031, г. Москва, ул. Большая Дмитровка, д. 24, стр. 1;

тел. +7(495) 625-71-63; факс +7 (495) 650-27-31;

Email: akimov@raasn.ru,pavel.akimov@gmail.com.

Малиновский Анатолий Павлович, доцент, кандидат технических наук, и.о. заведующего кафедрой строительной механики, Томский государственный архитектурно-строительный университет; 634003, Россия, г. Томск, Соляная пл. 2; e-mail: bat9203@gmail.com.

Leonid S. Lyakhovich, Full Member of the Russian Academy of Architecture and Construction Sciences, Professor, DSc, Head of Department of Structural Mechanics, Tomsk State University of Architecture and Building; 634003, Russia, Tomsk, Solyanaya St., 2;

E-mail: 1ls@tsuab.ru

Pavel A. Akimov, Full Member of the Russian Academy of Architecture and Construction Sciences, Professor, Dr.Sc.; Acting Rector of National Research Moscow State University of Civil Engineering; Professor of Department of Architecture and Construction, Peoples' Friendship University of Russia; Professor of Department of Structural Mechanics, Tomsk State University of Architecture and Building; 24, Ul. Bolshaya Dmitrovka, 107031, Moscow, Russia; phone +7(495) 625-71-63;

Fax: +7 (495) 650-27-31;

E-mail: akimov@raasn.ru,pavel.akimov@gmail.com.

Anatoly P. Malinowski, Associate Professor, Ph.D, H.T. Head of Department of Structural Mechanics, Tomsk State University of Architecture and Building; 634003, Russia, Tomsk, Solyanaya St., 2;

E-mail: bat9203@gmail.com. 